\title{
Incorporating Humanist Ethical Approach to Remedy Environmental “Abuses” in Ghana
}

\author{
Paul Appiah-Sekyere \\ University of Cape Coast
}

\begin{abstract}
The influence that traditional Ghanaian norms, taboos, and folktales had in ensuring environmental protection and sustainability has been greatly minimized by the inroads of foreign cultures and religions such as Christianity and Islam. Currently, modern methods of environmental protection and sustainability have not achieved the desired goals. As a result, Ghana is at the mercy of countless forms of environmental abuses to the extent that Ghana is ranked the seventh dirtiest nation and also second in open defecation worldwide. This paper examines how the incorporation of Humanist ethical principles to integrate with the traditional Ghanaian environmental taboos and modern technological methods to salvage the continuous and relentless environmental abuses in Ghana.
\end{abstract}

Keywords: Humanism, ethics, environment

\section{Introduction}

Before the advent of foreign religions such as Christianity and Islam, the traditional indigenous norms and taboos of Ghanaians could deal effectively with environmental problems. With reference to the 2010 census, currently, Christians and Muslims outnumber the traditionalists. Christians and Muslims had apparently usurped the influence the traditionalists but failed to put measures that can effectively respond to environmental challenges in Ghana. This study examines how the incorporation of the Humanist ethical principles that strongly affirms that the "conservation of nature is a moral value...," to integrate with traditional Ghanaian environmental taboos and modern technological methods to salvage Ghana from the continuous and relentless environmental abuses.

\section{Humanism}

Humanism is a Philosophy and value system that seeks the total wellbeing of humans here and now without any belief in a personal deity or "higher power."1 Albeit there are several definitions of Humanism each definition, however, captures the basic tenets of Humanism. The International Humanist and Ethical Union (IHEU), defines Humanism as follows:

Humanism is a democratic and ethical life stance which affirms that human beings have the right and responsibility to give meaning and shape to their own lives. It stands for the building of a humane society through an ethics based on human and other natural values in a spirit of reason and free inquiry through human capabilities. It is not theistic, and it does not accept supernatural views of reality. ${ }^{2}$ (American Humanist Association, 2014)

Paul Appiah-Sekyere, Ph.D., Department of Religion and Human Values, University of Cape Coast, Ghana; main research field: Ethics, Humanism, Religion, Poverty, and Environment. 
Humanism does not accept any supernatural reality. For Humanists, there is no heaven or hell, no netherworld. Humanism does not believe in immortality, the life hereafter and similar views that are espoused by some religions such as Christianity and Islam.

The American Humanist Association (AHA) also says that "Humanism is a progressive life stance that, without supernaturalism, affirms our ability and responsibility to lead meaningful, ethical lives capable of adding to the greater good of humanity” (http://www.americanhumanist.org).

Defining Humanism, the Bristol Humanist Group maintains that "Humanism is an approach to life based on reason and our common humanity, recognizing that moral values are properly founded on human nature and experience alone" (http://www.nfuu.org/definitionsofhumanism.htm).

The definition of the Bristol Humanist Group highlights the role of reason and the common nature of humans. All the aforementioned definitions clearly affirm that Humanism does not accept supernaturalism. Humanism believes that humans are naturally capable of living meaningful lives without any reference to God or supernatural being.

\section{Humanist Ethics and the Environment}

Singer (1993) asserts that ethics is the philosophical study of morality. He sometimes uses ethics and morality interchangeably. Ethics, also known as moral philosophy, involves systematizing, defending, and recommending concepts of right and wrong behavior (Fieser 2009). According to Boss (1997), ethics is a philosophical discipline that studies the values and guidelines by which we live, as well as the justification of these values and guidelines. In fact, ethics is a major branch of philosophy that addresses questions about morality - that is, concepts such as good and evil, right and wrong, virtue and vice. Gonsalves (1989) asserts that "ethics is both a practical and normative science that discovers, explains, and demonstrates the principles and rules of right conduct" (Gonsalves 1989, 7).

Humanist ethics, therefore, involves the values of right, wrong, good, evil, and responsibility according to the beliefs/teachings of Humanism. According to Humanist ethics, morality stems from our situation as social beings; the origin of morality/ethics is the human society without reference to any metaphysical or spiritual source; one can be morally upright without necessary being religious; Humanist ethics relies on reason and modern scientific method and does not have faith in prayer, divine revelation, or a supernatural God for the solution of ethical or other problems.

Paul Kurtz (1988) asserts that morality is deeply rooted in the common moral decencies (these relate to moral behavior in society) and the ethical excellences. Characteristically, the common moral decencies are widely shared. They are essential to the survival of any human community. They are handed down through countless generations. ${ }^{3}$ The common moral decencies include personal integrity, trustworthiness, benevolence, and the principle of fairness. Considering the peculiar relevance of benevolence to the issue of environmental sustainability, the discussion will give it a special attention.

Benevolence involves demonstrating goodwill and noble intention. In a further perspective, benevolence deals with trustworthiness and having a positive concern for other human beings. It means the lack of malice; avoidance of doing harm to other humans and their property. Benevolence implies that one should not kill or rob; inflict physical violence or injury; or be cruel, abusive or vengeful. For the Humanist, benevolence places an obligation ${ }^{4}$ on humans to be beneficent, meaning kind, sympathetic, compassionate and help those in distress and alleviate their pain and suffering and contribute positively to their wellbeing. 
In relation to the manifestation of goodwill and concern for other humans and contributing to their wellbeing as part of the moral decency of benevolence, ${ }^{5}$ Humanist ethics demands that the present generation uses the environment in a sustainable way such that the survival and wellbeing of the future generations of humans will not be jeopardized. ${ }^{6}$

Humanist ethics contains ethical excellences, which include: autonomy, intelligence and reason, self-discipline, self-respect, creativity, high motivation, affirmative attitude, joie de vivre, good health and exuberance. Because of their particular relevance to environmental issues, intelligence and reason, self-discipline and good health are given special treatment in this study.

For Humanism, intelligence and reason are high on the scale of values. This demands that in order to achieve the good life, one must develop one's cognitive skills to enable one to make wise choices. Of course, for such choices to be categorized as morally good or wise they should be choices that benefit humanity. Since humanity includes the present and future generations, it therefore becomes a sine qua non requirement that such choices take into consideration the sustainable use of the environment for the good of both the present and future generations.

Self-discipline: Self-discipline involves the utilization of the guidance of rational choice to help a human being to do things in moderation and avoid extremism. According to Humanism, one needs to satisfy one's desires and emotions. However, one must avoid the harmful consequences that imprudent choices can have upon the individual and others. Hence, the need for self-discipline over a person's passions and desires is an important ethical/moral value for Humanists. Self-disciplined humans would avoid indiscriminate littering, open defecation and other environmental abuses, and promote healthy environmental behavior.

Good health: For Humanists good health demands that the individual avoids smoking and drugs, drinks only in moderation, seeks to reduce stress in one's life, and strives to get proper nutrition, adequate exercise, and sufficient rest, and to achieve sexual fulfillment and love. One can obtain good health within a healthy environment, hence, the importance of a clean and healthy environment for good health.

Lamont (1980) summarizes Humanist ethics into eleven main points. He describes them as guiding principles not absolutes and they include:

(1) Humanist ethics is concerned wholly with actions, ideals, and values on this earth in our and only life. The utopia that is heaven must be built in this world or not at all.

(2) Humanist ethics is an affirmative one of joy and happiness, repudiating the Christian idea of original sin in human beings and any sense of Puritanism.

(3) Humanist ethics holds a liberal view on sex relations, but insists on high standards of conduct and believes in the institution of marriage, with easy divorce and some latitude of sexual variety for husband and wife.

(4) Humanist ethics relies on reason and scientific method in working out ethical decisions. There is no room for prayer or divine guidance by some supernatural being.

(5) While Humanism believes in general ethical principles, most ethical decisions must be considered on an individualistic basis that evaluates the probable consequences and possible alternatives.

(6) In the age-long dialogue on self-interest versus altruism, Humanist ethics sees a false dichotomy and claims that a man or woman can harmoniously combine relative self-interest and relative altruism in working for the community good. 
(7) The community good is one's family, one's state, one's nation, or all humanity; with the happiness and progress of the entire human race as the ultimate community good and the supreme ethical aim of Humanism.

(8) It follows from ordinary self-interest and the Humanist's concern for fellow humans that international peace is a principal ethical objective. This is truer today than ever before in view of the terrible nuclear weapons that have developed and which threaten, if used in a war, the existence of all humankind.

(9) Humanism is eclectic and incorporates whatever seems relevant from other philosophies or religions. For instance, many of the Christian precepts in the Old and New Testaments have an important place in the ethics of Humanism.

(10) The support for democracy and civil liberties is an ethical imperative for Humanism, with complete freedom of expression in every field of human endeavor.

(11) The Humanist ethics functions on the basis that human beings have true freedom of choice at the moment of making an ethical decision. Universal determinism that includes humankind would make any sort of ethics impossible and irrelevant.

Actually, Humanist ethics maintains that international peace is a principal ethical objective. In fact,

This world community must renounce the resort to violence and force as a method of solving international disputes. We believe in the peaceful adjudication of differences by international courts and by the development of the arts of negotiation and compromise. War is obsolete. So is the use of nuclear, biological, and chemical weapons. It is a planetary imperative to reduce the level of military expenditures and turn these savings to peaceful and people-oriented uses. ${ }^{7}$ (American Humanist Association, article 13)

In a related perspective, a question such as this can be raised, namely, can there be international peace if humans destroy their peaceful relation with the natural environment? For Humanist ethics, it is the moral duty of humans to use this planet in an intelligent sustainable manner and rid the universe of environmental abuses.

The world community must engage in cooperative planning concerning the use of rapidly depleting resources. The planet earth must be considered a single ecosystem. Ecological damage, resource depletion, and excessive population growth must be checked by international concord. The cultivation and conservation of nature is a moral value; we should perceive ourselves as integral to the sources of our being in nature. We must free our world from needless pollution and waste, responsibly guarding and creating wealth, both natural and human. Exploitation of natural resources, uncurbed by social conscience, must end. ${ }^{8}$ (American Humanist Association, article 14)

The aforementioned humanist ethical values, embodied in their stance that the "conservation of nature is a moral value...," coupled with the determination to save the world of unbridled exploitation of natural resources, are very important ingredients that can be incorporated by environmentalists and people of good will to integrate with traditional Ghanaian environmental protection methods and modern technological methods to salvage Ghana from the continuous and relentless environmental abuses.

\section{Ghana: Location}

Ghana, formerly known as the Gold Coast, is a West African nation that is bordered on the North by Burkina Faso, on the South by the Gulf of Guinea, on the East by the Republic of Togo, and on the West by La Cote D'Ivoire (Ivory Coast). Geographically, it is located between the Latitudes $4^{\circ} 44^{\prime}$ and $11^{\circ} 15^{\prime} \mathrm{N}$, of the Equator, and between the Longitudes $3^{\circ} 15^{\prime} \mathrm{W}$ and $1^{\circ} 12^{\prime} \mathrm{E}$ of the Greenwich Meridian. In fact, Ghana can be located precisely on Latitude $5^{\circ} 36^{\prime} \mathrm{N}$ and Longitude $0^{\circ} 10^{\prime} \mathrm{E}$ (http://www.ghanaweb.com/GhanaHomePage/G eography/nature.php). 
The total area of Ghana is 238,537 $\mathrm{km}^{2}$ (92,100 miles ${ }^{2}$ ) comprising land: $230,940 \mathrm{~km}^{2}$ and water: 8,520 $\mathrm{km}^{2}$ (http://www.ghanaweb.com/GhanaHomePage/general/statistics.php). Ghana has two major seasons, namely, the wet and dry seasons. With its proximity to the equator, Ghana has a climate that is characteristically tropical and humid. Actually, the climate is tropical. The eastern coastal belt is warm and comparatively dry; the southwest corner, hot and humid; and the north, hot and dry. There are two distinct rainy seasons in the south, May-June and August-September; in the north, the rainy seasons tend to merge. A dry, northeasterly wind, the Harmattan, blows in January and February (http://www.ghanaweb.com/GhanaHomePage/geography/nature.php).

The population of Ghana is about 24,658,823 (2010 Census). ${ }^{9}$ According to the 2010 Census, the ethnic groups in Ghana are Akan (47.5\%), Mole-Dagbani (16.6\%), Ewe (13.9\%) and Ga-Dangme (7.4\%), Gurma (5.7\%), Guan (3.7\%), Grusi (2.5\%), Mande (1.1\%), other (1.6\%). ${ }^{10}$ As regards the religions in Ghana, the 2010 Census declared that there are Traditionalists (5.2\%), Christians (71.2\%), Muslims (17.6\%) and others (0.8\%), None (5.3\%). ${ }^{11}$

\section{Environmental Abuses}

There are different dimensions of environment. ${ }^{12}$ This paper focuses on the physical or natural aspect of environment. Before the advent of foreign cultures and religions such as Christianity and Islam, traditional Ghanaian norms and taboos effectively ensured environmental protection and sustainability. ${ }^{13}$ With the advent of foreign culture and Christianity, ${ }^{14}$ the influence of traditional Ghanaian norms and taboos in ensuring environmental protection and sustainability has gradually reduced to the barest minimum. Considering the present environmental situation in Ghana, it is obvious that the borrowed culture(s) and religions have also not been as successful as the traditional Ghanaian norms and taboos, in ensuring environmental protection and sustainability in Ghana. Currently, the abuses that occur in the use of the natural environment in Ghana are numerous. Thus, a selective methodological approach is employed in treating the environmental abuses that can contribute towards achieving the objectives of this study.

\subsection{Deforestation}

According to Tamakloe (2008), since the 1940s, more than $90 \%$ of the forest in Ghana has been destroyed and the destruction of the forest continues. In fact, illegal logging is causing deforestation and thereby contributing its quota to desertification and climate change. According to the Ghana News Agency (GNA), the original forest cover in Ghana was 36\% of the nation's landmass and reduced to 23\% by 1972, 13.3\% in 1990 and 10.2\% in 2000 (GNA, 2006). Presently, GNA quotes Kyere Boateng as saying: "We have come to realize that some 85 communities encourage illegal logging in 85 forest reserves for financial benefits because they did not receive adequate compensation” (GNA, February 12, 2011, 1; http://www.ghanaweb.com/). Albeit in 1988 Ghana initiated a conservation plan called the Forest Resource Management Project and in 1989 Ghana restricted the export of 18 tree species, and again in 1994 Ghana banned the export of raw logs, illegal logging threatens Ghana's remaining forests. ${ }^{15}$

In addition to logging, bush fires are also destroying the environment at an alarming rate. This was affirmed by Mr. Abu Iddrisu, the Northern Regional Manager of the Environmental Protection Agency (EPA) when he expressed worry about the rate at which the environment was being depleted due to excessive bush burning. ${ }^{16}$ Apart from destroying the environment, bush fires sometimes destroy crops. For example, a report 
by The Ghana News Agency (GNA) stated, "Raging bushfire has destroyed three rice farms in the Yendi Municipality from January to March this year." ${ }^{, 17}$

Different governments, Churches and Non-Governmental Organizations (NGOs) and individuals of good-will have spoken against the destruction caused by bush fires in Ghana. It seems that the perpetrators of the bush fires place their individual selfish interests above the national interest. ${ }^{18}$ Consequently, data estimate that every year, bush fires destroy about $30 \%$ of the forest area in Ghana. ${ }^{19}$

In a related development, whereas in the late 19th century, hardwood forests covered the southern half of Ghana, considerable portions of these once-extensive forests have been destroyed. In fact, within (1990-1996) about $1.3 \%$ of the remaining forest was lost every year. ${ }^{20}$

\subsection{Open Defecation}

A joint sanitation report by WHO and UNICEF ranked Ghana as one of the dirtiest countries on Earth. The report further revealed that: "Ghana's access to household toilets is only $15 \%$. It is one of the lowest sanitation coverage in the world. The situation with sanitation coverage is worse only in Sierra Leone, ranked 13\%, Chad, Madagascar and Togo, ranked $12 \%$ each, Niger, ranked $11 \%$ and South Sudan, which has a 7\%” (2016). ${ }^{21}$

The lack of toilet facilities is one of the factors causing open defecation. ${ }^{22}$ In the fight against open defecation, Kamal Kar, founder and chairman of the World-wide Community Led Total Sanitation (CLTS) Foundation, appealed to the Ghana government to demonstrate the political will towards eradicating open defecation in the country. ${ }^{23}$ Actually, Kar's CLTS Foundation is "spearheading a world-wide campaign to eradicate open defecation in countries where the practice is a major public health problem. The campaign in Ghana focuses on the Volta, Central, Northern, Upper-East and Upper-West Regions, where open defecation is said to be endemic in many districts and communities."24

\subsection{Sanitation and Water Bodies}

Considering the magnitude of the sanitation challenges in Ghana, this study cannot claim to exhaustively discuss all of them. However, it seems reasonable to have at least a candle in the midst of total darkness. ${ }^{25}$ That fighting sanitation problem must be a top priority in Ghana, even the embryo in the womb of a pregnant Ghanaian woman seems to be aware of this fact. ${ }^{26}$ Fiergbor, L. (3/5/2013), rightly states that:

\footnotetext{
Sanitation problem has been in this country for many years, but the sad story is that, each and every day, the problem of sanitation is not solved or cannot be solved, rather the situation gets out of hand every day at a speed that if we are not careful, we cannot even move from one point to the other because everywhere is garbage. The choked Chemu Lagoon, until steps are taken to control the dumping of garbage into the lagoon the channel will remain choked, even if it is dredged regularly. This is because residents alongside the lagoon dump into the lagoon solid waste instead... It is not only the Chemu Lagoon which is suffering this fate, the Odaw River, the Korle Lagoon, the Onyasia drain and others, country wide. The contamination of the river has made all aquatic creatures impossible to live. Until we change our minds, attitudes and realizing that we are killing our own selves, government cannot do anything about, we will all die gradually through sicknesses and diseases and artificial disasters caused by our own doing. Examples like outbreak of cholera, TB, malaria, diarrhea... ${ }^{27}$ (2016)
}

It seems that government cannot do anything about it considering the magnitude of the sanitation challenges in Ghana. It could also be that successive governments in Ghana have been giving the sanitation problem very "weak" attention. This is affirmed by Kamal Kar, the founder and chairman of the World-wide Community Led Total Sanitation (CLTS) Foundation when he asserted that "Madagascar and others, 
comparatively less endowed than Ghana, were able to eliminate the practice totally because of the strong political will” (2015). ${ }^{28}$

In 1992, United Nations Conference on Environment and Development (UNCED) recommended the celebration of World Fresh Water Day. The UN General Assembly accepted the recommendation and designated 22nd March, 1993 as the first World Fresh Water Day and since then, every year on 22nd March, Ghana joins the rest of the world to celebrate World Fresh Water Day. The day is set aside to create awareness and focus attention on the importance of fresh water as well as advocate for the sustainable use and management of fresh water bodies.

Despite the aforementioned effort to safeguard fresh water bodies, water pollution ${ }^{29}$ is deplorable in Ghana. Actually,

in Ghana, the effects of the activities of mining companies on water bodies through dewatering, ground water pollution, the free use of water for mining operations, pollution of streams through cyanide and other waste spillages, are contributing enormously to impoverishing the communities who live around their operational areas. ${ }^{30}$ (Ziem 2013)

\section{Evaluation}

It is crystal clear from the above discussions that the environmental situation in Ghana is deplorable. Obviously, some efforts to remedy the situation are going on. It seems, however, that the efforts are not achieving the desired goals. The above discussions have also treated the Humanist ethical approach towards the environment. Considering the fact that majority of Ghanaians are Christians and/or Muslims or Traditionalists, this study argues that one very probable methodological strategy to holistically remedy the environmental abuses in Ghana, is to incorporate the Humanist ethical approach to supplement the efforts by Ghanaian Christians, Muslims, and Traditionalists.

Just as Ghanaian Christians, Muslims and Traditionalists claim to seek the wellbeing of their fellow humans; Humanism also seeks the wellbeing of the same humans. Furthermore, both the former and later acknowledge that human beings live in society and have moral and social responsibilities.

Whereas the ethics of Christianity, Islam and African Traditional Religion place emphasis on the vertical and horizontal dimensions, corresponding to the individual human being's relationship with God/Allah/Supreme Being and his or her fellow humans in the society respectively, Humanist ethics places emphasis on the horizontal, namely, the individual's social and planetary responsibilities. ${ }^{31}$ It seems that the contemporary Ghanaian thinks of what he/she can get from Ghana and not what he/she can give to Ghana. ${ }^{32}$ Consequently, many people do not take their responsibilities towards the nation seriously. In this context, a call from Humanist ethics that places emphasis on one's social and planetary responsibilities, including the environment, cannot be overemphasized.

Christianity, Islam, and Traditional religions, respectively, make reference to a God or Allah or a supreme being in their respective ethics. Thus, there is a supernatural force behind their respective ethical principles. These religious based ethical principles seem to be ineffective in preventing environmental abuses in Ghana. Humanist ethics (without any reference to any supernatural being) ${ }^{33}$ makes reference to human reason and scientific knowledge as the basis that provide the guiding principles for the individual's moral and social responsibilities. These responsibilities, of course, include those that deal directly or indirectly with the sustainable use of the environment for the wellbeing of both the present and future generations. 
Ghanaian Christians, Muslims, and Traditionalists believe that there is an omnipotent supernatural creator that continues to be in charge of the world. This implies that majority of Ghanaians believe that the omnipotent creator continues to be in charge of the universe including Ghana. The dangerous temptation therefore is that majority of Ghanaians may think that even if they fail to preserve, conserve, reserve, and protect the natural environment and use it sustainably, their all-powerful supernatural creator will never fail to replenish and sustain it for them since the said creator is in charge. If this hypothesis is true, or even $50 \%$ true, then the obvious repercussion is the offloading of our human responsibility towards the environment on the aforementioned supernatural being who never fails "for nothing is impossible to God" ${ }^{\text {"34 }}$ (perhaps including salvaging the environmental abuses of Ghanaians).

According to Humanism, the belief that a supernatural deity will save us—-humans and the world is a myth. Furthermore, "Salvationism" is a distraction from the pressing problems of the present life. ${ }^{35}$ Humanist ethics, with its great emphasis on the human being's social and planetary responsibilities, places a rational, pragmatic and realistic demand on humans (in this specific context, Ghanaians) to be responsible for the conservation, reservation and sustainability of the natural environment instead of relinquishing that responsibility into the hands of a supernatural being.

In a further perspective, Humanist ethics promotes the community of humanity. ${ }^{36}$ This has some bearing on the African sense of "we" communalism that is an important Ghanaian cultural value. ${ }^{37}$ The interrelatedness of human beings in a community, found in both Humanist ethics ${ }^{38}$ and Ghanaian culture, is a very pragmatic springboard that can be utilized to actualize the vision of promoting the wellbeing of fellow humans here and now, in this present life, which includes avoiding the aforementioned environmental abuses since the said abuses are harmful to the wellbeing and survival of the human community. Indeed, "We are responsible for what we are or will be... We will survive and prosper only in a world of shared humane values."39

Life hereafter, heaven, and hell are some of the beliefs cherished by Christians, Muslims, and Traditionalists. Considering the religious nature of Ghanaians, ${ }^{40}$ and juxtaposing the apparent laiser faire attitude of Ghanaians towards the natural environment, one may deduce that it is highly probable that Ghanaian Christians, Muslims, and Traditionalists (forming the majority of the population) are seemingly more interested in the better, spotless, holy, supernatural life hereafter than in this dirty, disease-filled, unhappy present natural life. In this spectrum, the Humanist stance to create a heaven here and now in this present life by eliminating, diseases (which of course involves clean and healthy environment), poverty, and seek happiness ${ }^{41}$ and wellbeing for humans (since people are more important than decalogues, rules, proscriptions, or regulations) ${ }^{42}$ is worth-incorporating to salvage the environmental abuses in Ghana.

\section{Conclusion}

Albeit Ghanaians are basically religious, and are very familiar with a proverb that says "Nyame boa nyimpa a oboa ne ho" (heaven helps those who help themselves); we are failing to help ourselves in terms of the sustainable use of our natural environment. Unfortunately, this failure has awarded Ghanaians with disgraceful titles such as the seventh dirtiest nation and second in open defecation worldwide. This paper has endeavored to explore how the incorporation of Humanist ethical principles can augment the efforts of Ghanaian Christians, Muslims, and Traditionalists to salvage the environmental abuses in Ghana. Notwithstanding the dissimilarity in the God factor, the shared ethical values such as one's social and communal responsibilities among Humanists and Ghanaian Christians, Muslims, and Traditionalists are 
significant ingredients that can facilitate the aforementioned incorporation. The achievement of this objective is very probable because the Ghanaian is characteristically communalistic and in a similar vein, the Humanist wants to preserve his/her own life as well as the lives of his/her fellow humans. ${ }^{43}$

\section{Notes}

1. American Humanist Association, Humanist Manifestos I \&II. <http://www.americanhumanist.org>. 03/03/2014.

2. American Humanist Association, Humanist Manifestos I \& II. <http://www.americanhumanist.org>. 03/03/2014; $<$ http://www.iheu.org/amsterdamdeclaration>.

3. On the common moral decencies, see Kurtz, P. (1988). Forbidden Fruit: The Ethics of Humanism. N.Y.: Prometheus Books. Kurtz maintains that these common moral decencies are trans-cultural in their range and have their roots in generic human needs. Examples of the common moral decencies are personal integrity, trustworthiness, benevolence, and the principle of fairness.

4. Humanism does not accept any supernatural force behind morality since they find insufficient evidence for belief in the existence of a supernatural (American Humanist Association, Humanist Manifesto II, article 1). Rather, it is practical moral wisdom that recognizes the obligatory nature of responsible conduct which includes responsible and sustainable use of the environment.

5. According to humanist ethics, the moral decencies need not be divinely ordained to have moral force, for they are tested in the last analysis by their consequences in practice. Morally developed human beings accept these principles and attempt to live by them because they understand that some personal moral sacrifices may be necessary to avoid conflict in living and working together (Kurtz, P. 1988, Op. Cit.).

6. This is in line with the humanist ethical principle that the Humanist wants to preserve his/her own life as well as the lives of his/her fellow humans (Lamont 1980).

7. American Humanist Association, Manifesto II, article 13.

8. American Humanist Association, Humanist Manifesto II, article 14.

9. Ghana Statistical Service (May, 2012), 2010 Population \& Housing Census. Summary Report of Final Results. Accra: A Publication of the Ghana Statistical Service (Sakoa Press Limited).

10. Ghana Statistical Service (May, 2012), 2010 Population \& Housing Census. Summary Report of Final Results, 34.

11. Ghana Statistical Service (May, 2012), 2010 Population \& Housing Census. Summary Report of Final Results, 40.

12. Examples include social, political, religious, economic, and natural dimensions of environment. <http://www.unep.org>.

13. Traditional Ghanaian methods that ensured environmental protection and sustainability included sacred groves, folktales, totemic animals and taboos (Awuah-Nyamekye, S. 2014). Managing the Environmental Crisis in Ghana: The Role of Traditional African Religion and Culture with Special Reference to the Berekum Traditional Area. Newcastle: Cambridge Scholars Publishing, 90-128; Sarpong, P. (1974). Ghana in Retrospect: Some Aspects of Ghanaian Culture (reprint 2006). Accra: Ghana Publishing Corporation, 51-63; That traditional Africans (including traditional Ghanaians) utilized their traditional environmental methods to ensure ecological balance and sanity, Mbiti (1991), 44.

14. On the advent of foreign culture(s) and Christianity, Wiltgen, R. M. (1956), Gold Coast Mission History 1471-1880. Techny, Illinois: Divine Word Publications, 1-10.

15. <http://www.ghanaweb.com/GhanaHomePage/geography/nature.php>.

16. GNA (4th February, 2011). Nine people to be prosecuted for indiscriminate bush burning. $<$ http://www.ghanaweb.com/GhanaHomePage/crime/artikel.php?ID=202>. 05/04/2011.

17. GNA (21st April, 2011). <http://www.ghanaweb.com/GhanaHomerPage/regional/artikel.php?ID=207322>. 06/05/2011.

18. Appiah-Sekyere, P. (2011). Humanist Ethics: Its Relevance in Ghana Today. Integrative Humanist Journal, Vol. 1, No. 1, 15.

19. <http://www.allafrica.com/stories/>; Appiah-Sekyere, P. (2011). Humanist Ethics: Its Relevance in Ghana Today. Integrative Humanist Journal, Vol. 1, No. 1, 15.

20. <http://www.ghanaweb.com/GhanaHomePage/geography/nature.php>.

21. WHO and UNICEF joint report, "5 Facts about Ghana as One of the World's Dirtiest Countries." $<$ https://yen.com.gh/15343-5-facts-ghana-one-dirtiest-countries-world.html>, 3rd May, 2016.

22 . On open defecation, Taylor M. E. (19/11/2015), Ghana ranked 2nd in open defecation. $<$ http://pulse.com.gh/health/world-toilet-day-ghana-ranked-2nd-in-open-defecation>, 4th May, 2016.

23 . GNA (19th May, 2015). Ghana charged to eliminate open-defecation. <http://www.ghananewsagency.org/health/ghana-must-show-political-will-towards-eliminating-open-defecation-foundation-89565>.

24. Ibid.

25. If a joint report from renowned institutions such as WHO and UNICEF ranked Ghana as one of the dirtiest countries on Earth, and further states that "... more than 7,500 Ghanaian children die from diarrhea every year. This impressive death toll is caused by poor hygiene and bad sanitation," then the sanitation situation in Ghana is or not far from total darkness. For the WHO and UNICEF joint report, "5 Facts about Ghana as One of the World's Dirtiest Countries." <https://yen.com.gh/15343-5-facts-ghana-one-dirtiest-countries-world.html>, 3rd May, 2016. 
26. After all, it can be logically deduced that when poor sanitation in Ghana causes cholera, diarrhea, dysentery, malaria, and the like, the effects can obviously affect both the embryo and the pregnant mother in Ghana. For example, $<$ http://rainbowradioonline.com/> (8th May, 2016), Cholera alert: Upper West Akyem Engulfed in Filth, $<$ http://www.ghanaweb.com/GhanaHomePage/health/Cholera-alert-Upper-West-Akyem-engulfed-in-filth-436886>, 10/5/16.

27. Fiergbor, L. (3/5/2013). <http://lawrenceofoefiergbor.blogspot.com/2013_05_01_archive.html>, 4th May, 2016.

28 . GNA (19th May, 2015). Ghana charged to eliminate open-defecation, $<$ http://www.ghananewsagency.org/health/ghana-must-show-political-will-towards-eliminating-open-defecation-foundation-8956 $5>$.

29. Water pollution can be as anything humans do to cause harmful effects to water bodies. This can include pollution of rivers, lakes, oceans, and ground water pollution. Ziem, J. (30 April 2013), Ghanaians Must Protect Fresh Water Resources, <http://www.ghanaweb.com/GhanaHomePage/NewsArchive/Ghanaians-Must-Protect-Fresh-Water-Resources-272519>, 2nd May, 2016.

30. Ziem, J. (30 April 2013), Ghanaians Must Protect Fresh Water Resources, Ibid.; footnote 24 above. 15.

31. Appiah-Sekyere, P. (2011). Humanist Ethics: Its Relevance in Ghana Today. Integrative Humanist Journal, Vol. 1, No. 1,

32. Ibid.

33. American Humanist Association, Humanist Manifesto II, article one.

34. Luke 1:37.

35. Budziszewski, J. (March 2000). The Humanist Manifestos (1933; 1973; 1999).

36. American Humanist Association, Humanist Manifesto II, articles 10-closing.

37. Gyekye, K. (2003). African Cultural Values. Legon, Ghana: Sankofa Publishing Company. 35-36.

38. Humanist ethics affirms that "each person's future is in some way linked to all. We thus reaffirm a commitment to the building of world community, at the same time recognizing that this commits us to some hard choices" (American Humanist Association, Humanist Manifesto II, article 12).

39. American Humanist Association, Humanist Manifesto II, closing.

40. That "Africans are notoriously religious,” Mbiti $(1997,1)$, and by Parrinder who sees the African as "incurably religious,” confer Parrinder $(1961,9)$. On the religious nature of the Ghanaian/African see also Asare Opoku, K. who rightly opines that "in traditional Africa, religion is life and life, religion. Africans are engaged in religion in whatever they do—whether it be farming, fishing or hunting; or simply eating, drinking or travelling. Religion gives meaning to their lives” (Asare Opoku, K. 1978, 1).

41. American Humanist Association, Humanist Manifesto II, article 10.

42. American Humanist Association, Humanist Manifesto II, article 8.

43. Lamont (1980). “The Affirmative of Humanism.” The Humanist Magazine, Vol. 40 (2) March/April.

\section{Works Cited}

American Humanist Association. Humanist Manifestos I \& II. <http://www.americanhumanist.org>. 03/03/2014.

Appiah-Sekyere, P. “Humanist Ethics: Its Relevance in Ghana Today.” Integrative Humanist Journal 1. 1 (2011): 3-19.

Awuah-Nyamekye, S. Managing the Environmental Crisis in Ghana: The Role of Traditional African Religion and Culture with

Special Reference to the Berekum Traditional Area. Newcastle: Cambridge Scolars Publishing, 2014. Boss, J. A. Perspectives

on Ethics. California: Mayfield Publishing Company, 1997.

Budziszewski, J. “The Humanist Manifestos.” 1933; 1973; 1999.

Ghana Statistical Service. 2010 Population \& Housing Census. Summary Report of Final Results. Accra: A Publication of the

Ghana Statistical Service (Sakoa Press Limited). May, 2012.

Fiergbor L. <http://lawrenceofoefiergbor.blogspot.com/2013_05_01_archive.html>.4th May, 2016.

Fieser, J. "Ethics." <http://www.iep.utm.edu/ethics/>. 2009.

GNA. "Nine People to Be Prosecuted for Indiscriminate Bush Burning."

<http://www.ghanaweb.com/GhanaHomePage/crime/artikel.php?ID=202>. 05/04/2011.

GNA. <http://www.ghanaweb.com/>. 11/10/2009.

GNA. "World Bank to Fight Climate Change in Ghana." <http://www.ghanaweb.com/>. 12/02/2011.

GNA. <http://www.ghanaweb.com/GhanaHome Page/regional/artikel.php?ID=207322>. 06/05/2011.

GNA. "Ghana Charged to Eliminate Open-Defecation."

<http://www.ghananewsagency.org/health/ghana-must-show-political-will-towards-eliminating-open-defecation-foundation89565>. <http://rainbowradioonline.com/> (8th May, 2016). Cholera alert: Upper West Akyem Engulfed in Filth, $<$ http://www.ghanaweb.com/GhanaHomePage/health/Cholera-alert-Upper-West-Akyem-engulfed-in-filth-436886>.

10/05/2016. 
GNA. "Ghana Charged to Eliminate Open-Defecation."

$<$ http://www.ghananewsagency.org/health/ghana-must-show-political-will-towards-eliminating-open-defecation-foundation89565>. 08/05/2016.

Gonsalves, M. Fagothey's Right \& Reason: Ethics in Theory and Practice. New Jersey: Prentice Hall, 1989.

Gyekye, K. African Cultural Values. Legon, Ghana: Sankofa Publishing Company, 2003.

Jones, A. The Jerusalem Bible, Standard English Version. London: Darton, Longman \& Todd, 1966.

Kurtz, P. Forbidden Fruit: The Ethics of Humanism. N.Y.: Prometheus Books, 1988.

Lamont, C. “The Affirmative of Humanism.” The Humanist Magazine 40. 2 (1980): March/April.

Lamont, C. The Philosophy of Humanism. 8th ed. Amherst, N.Y.: Humanist Press, 1997.

Mbiti, J. S. Introduction to African Religion. 2nd ed. Nairobi, Kampala, Dar es Salam: African Educational Publishers, 1991.

Mbiti, J. S. African Religions and Philosophy. London: Heinemann, 1997.

Opoku, K. A. West African Traditional Religion. Accra and BangKok: Fep International Private Limited, 1978.

Parrinder, G. West African Religion: A Study of the Beliefs and Practices of Akan, Ewe, Yoruba, Ibo and Kindred People. London: The Epworth Press, 1961.

Parrinder, E. G. Religion in Africa. Harmondsworth: Penguin, 1969.

Sarpong, P. Ghana in Retrospect: Some Aspects of Ghanaian Culture. Reprint 2006. Accra: Ghana Publishing Corporation, 1974.

Singer, P. A Companion to Ethics. Mass.: Blackwell, 1993.

Tamakloe, W. "State of Ghana's Environment Challenges of Compliance and Enforcement, 2008." $<$ http://www.inece.org/indicators/proceedings/04h_ghana.pdf>. 04/05/2015.

Taylor M. "Ghana E. Ranked 2nd in Open Defecation." <http://pulse.com.gh/health/world-toilet-day-ghana-ranked-2nd-in-open-defecation>. 04 /05//2016.

WHO and UNICEF Joint Report. "5 Facts about Ghana as One of the World's Dirtiest Countries." <https://yen.com.gh/15343-5-facts-ghana-one-dirtiest-countries-world.html>. 03/05/2016.

Wiltgen, R. M. Gold Coast Mission History 1471-1880. Techny, Illinois: Divine Word Publications, 1956.

Ziem, "Ghanaians Must Protect Fresh Wesources." <http://www.ghanaweb.com/GhanaHomePage/NewsArchive/Ghanaians-Must-Protect-Fresh-Water-Resources-272519>. 02 /05/2016.

$<$ http://www.ghanaweb.com/GhanaHomePage/geography/nature.php>.

$<$ http://www. Corliss-lamont.org/ethics.htm>. 04/03/2013.

$<$ http://www.iheu.org/amsterdamdeclaration>. 04/02/2013.

$<$ http://www.allafrica.com/stories/>. 20/12/2013.

$<$ http://www.ghanaweb.com>. 17/06/2014.

$<$ http://www.unep.org>. 03/05/2015.

$<$ https://yen.com.gh/15343-5-facts-ghana-one-dirtiest-countries-world.html>. 03/05/2016.

<http://lawrenceofoefiergbor.blogspot.com/2013_05_01_archive.html>. 04/05/2016.

<http://rainbowradioonline.com/> (8th May 2016). "Cholera Alert: Upper West Akyem Engulfed in Filth." $<$ http://www.ghanaweb.com/GhanaHomePage/health/Cholera-alert-Upper-West-Akyem-engulfed-in-filth-436886> 10/05/2016.

<http://www.nfuu.org/definitionsofhumanism.htm>. 08/02/2014. 